So we say that the public from long communion with these huge transactions now takes them as a matter of course, but without fully understand- ing that it is the wonderful working of the Federal Reserve System which makes us commercially and financially what we are.

\title{
Eligibility for Discount
}

\author{
By Charles I. Poweln \\ Counsel for Federal Reserve Bank of Chicago
}

$\mathrm{T}$ THE kind and character of paper which the Federal Reserve Banks may discount for member banks is in broad general terms defined in Section 13 of the Federal Reserve Act. It is there provided that the Federal Reserve Banks, upon the endorsement of member banks, may discount for them: (1) notes, drafts and bills of exchange issued or drawn for agricultural, industrial or commercial purposes, or the proceeds of which have been used or are to be used for such purposes; (2) acceptances of banks of the character and kind described in the Act.

The Federal Reserve Board, by the same section of the Act, is given the right to determine or define the character of paper made eligible for discount within the meaning of the Act; and, the Board in the exercise of this statutory right has, from time to time, promulgated a series of regulations for the guidance of the Federal Reserve Banks and member banks. These regulations, while not a part of the statute, having been made and promulgated by a lawfully constituted body, have the force and effect of law. ${ }^{1}$ As is said by the Supreme Court of the United States, in United States v. Clark, "the Legislature cannot delegate its powers to make a law, but it can make a law to delegate a power to

1 United States v. Grimaud, 220 U. S. 506; Dasterbignes Case, 122 Fed. 30; United States v. Clark, 143 U. S. 664. determine some fact or state of things, upon which the law makes, or intends to make, its own action depend." Accordingly, the regulations made by the Federal Reserve Board defining, applying and limiting the character of paper eligible for rediscount must be read as part of the Act.

General Limitations on Eligibility

The limitations on eligibility for discount, as provided by the Act and the regulations of the Board, are directed to (1) the maturity of the paper and (2) its source of origin, or the purposes for which it is to be used. The language used by the Act in respect to the latter is modeled upon many prior proposals for legislation and was manifestly for the purpose of avoiding the use of bank funds in two general classes of transactions, that is to say, in speculative transactions and in transactions involving capital investments.

The reason for these two provisions of the Act-the one relating to the origin or purpose of the note or bill and the other to its short maturity-is found in the recognized necessity of keeping the assets of the bank liquid at all times and thus readily available to meet the demands of commerce and trade.

It was expected, and the operation of the Act has proved it to be the case, that a large part of the banking resources of the nation would find its way into the 
Reserve Banks. It was, and is, unthinkable, from a scientific standpoint, that these resources should be tied up in long-time investments, or in investments permanent in their nature. It is the very essence of the Federal Reserve System that its funds must be invested in short-time securities, which, in theory at least, are self-liquidating.

\section{Board Definitions of Eligible PAPER}

Regulations of the Federal Reserve Board have been promulgated and put into effect, clarifying, amplifying and explaining the language of the Act, keeping in view at all times the broad general provision of the Act that investments must be of short maturity and must have arisen out of commercial transactions. These regulations have been revised from time to time. The last revision was put out under date of October 6, 1920.2 This revision was amended May 6, 1921. ${ }^{3}$

The Board's regulations define with particularity promissory notes, drafts, bills of exchange, trade acceptances, six months' agricultural paper and bankers' acceptances eligible for discount, but the definitions thus promulgated by the Board are well within the usual definitions found in the $\mathrm{Ne}$ gotiable Instruments Acts of the various states, so far as such acts deal with similar instrumentalities of commerce.

In addition to definitions of such ordinary instruments, a trade acceptance is defined as " a draft or bill of exchange, drawn by the seller on the purchaser of goods sold, and accepted by such purchaser."

Six months' agricultural paper is defined as "a note, draft, bill of exchange or trade acceptance, the proceeds of which have been used, or are to be used, for agricultural purposes, in-

2 Federal Reserve Bulletin, 6: 1179.

3 Ibid, $7: 54.5$. cluding the breeding, raising, fattening or marketing of live stock, and which has a maturity at the time of discount of not more than six months, exclusive of days of grace."

\section{Commercial and Agricultural Purposes Defined}

Under the regulations, paper may be eligible because issued or drawn for an agricultural or commercial purpose, or it may be eligible because the proceeds have been, or are to be, used for an agricultural or commercial purpose. The purchase and sale of goods of any character is a commercial transaction from the standpoint of the seller, and the note of a buyer given to the seller in payment for articles purchased is a note which has been "issued or drawn for a commercial purpose."

The use of the proceeds of a note to purchase goods for re-sale is a commercial purpose, even though the articles purchased will be permanent investments in the hands of the final purchaser; and, accordingly, the note of a dealer, discounted by him at a local bank, to provide funds to purchase articles for re-sale, may be eligible for discount as commercial paper, irrespective of the character of the articles purchased; but a note of a farmer discounted by him at his local bank to provide funds with which to purchase articles for agricultural uses, is eligible or ineligible for discount according to the character of the articles. If the articles are in the nature of permanent or fixed investments, then it is not eligible; but if, on the other hand, they are articles for agricultural uses and have to be replaced from time to time, the farmer's note is eligible for discount as agricultural paper.

The distinction between agricultural paper and commercial paper is important in several respects: Agricultural paper having a maturity of 
six months may be eligible, while commercial paper to be eligible can have a maturity of but three months; a farmer's note given in payment for articles or commodities to be used by the farmer for agricultural purposes is agricultural paper; but the purchase and sale of agricultural products is a commercial and not an agricultural transaction, and a note given to a farmer for agricultural products grown by him, is eligible, if at all, as commercial paper. ${ }^{4}$

\section{Long-Time Funds and Government Bonds}

The Board's regulations, following the provisions of the Act, provide for the discount by Federal Reserve Banks of such notes, drafts, bills of exchange, trade acceptances, six months' agricultural paper and bankers' acceptances of short maturity and of commercial origin referred to therein, but such regulations, following and expressing the spirit of the Act, provide that a note, draft, or bill of exchange, the proceeds of which have been used for permanent or fixed investments, such as lands, buildings, machinery and other capital purposes, or which have been used, or are to be used, for investments of purely speculative character, or for the lending to some other borrower, shall not be eligible for discount.

Both the provisions of the Act and the regulations of the Board make eligible for discount obligations issued or drawn for the purpose of carrying or trading in bonds and notes of the government of the United States, when such obligations are of proper maturity. Further, the Federal Reserve Act was, in effect, amended by the War Finance Corporation Act, approved April 5th, 1918, whereby obligations of appropriate maturity, as

Ibid., 6: 1302. defined by the Federal Reserve Act, when secured by bonds of the War Finance Corporation, are made eligible for discount. However, notes, drafts or bills issued or drawn for the purpose of carrying or trading in other stocks and bonds are not eligible for discount.

Strict negotiability of instruments of commerce is one of the prime requisites of paper eligible for discount by a Federal Reserve Bank. This is for the reason that a member bank must endorse paper tendered for discount, not only for the purpose of placing the title thereof in the Federal Reserve Bank, but also for the purpose of assuming all the responsibilities of an endorser upon negotiable paper. To the end that such liability of member banks, as endorser, be preserved, the instrument tendered for rediscount must be strictly negotiable within the meaning of the law applicable to commercial paper in the particular jurisdiction.

The Federal Reserve Board has promulgated rules for the determination of the eligibility of paper for discount, which rules have to do merely with the method to be pursued by the Federal Reserve Banks in ascertaining the ultimate facts as to whether or not the paper is eligible under the provisions of the Act and the regulations of the Board; but such regulations are evidenciary in effect and have to do, not with the eligibility of the paper, but merely with the method of procedure in ascertaining its eligibility.

\section{Commerctal and Agricultural Paper Eligible for Discount}

Notes secured by mortgage, if otherwise eligible, may be discounted. ${ }^{5}$ Inasmuch as notes payable "on or before" a given date are negotiable within the meaning of the Negotiable Instruments Act, in force in most of

${ }^{5}$ Ibid., 2 : 679. 
the states, and under the Law Merchant, such notes are eligible for discount. ${ }^{6}$ The assignment of an open account is not negotiable, and is not eligible for rediscount. ${ }^{7}$

A bill of exchange drawn by the seller on the purchaser of advertising space and accepted by such purchaser is a trade acceptance and is eligible for discount. $^{8}$ The note of a farmer held by a member bank, given for the purpose of assisting the farmer to produce a crop or to fatten his cattle, is eligible for discount if of proper maturity, whether or not secured by mortgage. ${ }^{9}$ A note drawn for commercial purposes, otherwise eligible for rediscount, is not ineligible because it is secured by a mortgage on real estate. ${ }^{10}$ The notes of a water works company, the proceeds of which have been, or are to be used to provide funds for the pay roll, purchase of coal and the like, are eligible for discount. ${ }^{11}$ The note of a packing company, the proceeds of which are used for the purchase of live stock for slaughter is not "based on live stock" within the meaning of Section 13 and is not eligible for discount if it has a maturity in excess of 90 days. ${ }^{12} \mathrm{~A}$ certificate of participation in a note, which, itself, is eligible for discount, is not eligible. ${ }^{13}$ Water sold by an irrigation company to farmers and delivered through the company's ditches may be classed as "goods sold," within the meaning of the Board's regulations and a note representing the agreed purchase price thereof is eligible for discount. ${ }^{14}$ Natural gas actually sold and delivered is "goods sold" and a trade acceptance covering such is eligible for discount. ${ }^{15}$

The note of the owner of property

- Federal Reserve Bulletin, 2: 394.
7 Ibid., 2: 227.
8 Ibid., 3: 116.
Ibid., 3 : 378.
10 Ibid., 3: 458. ${ }^{15}$ Ibid., 4: 435. which is to be developed or built up, the proceeds of which note have been, or are to be used by him to pay for the work of developing or building, is not eligible for discount, but the note of an owner given in good faith to the contractor in actual payment of material and services furnished by him for the owner, may be considered technically eligible for discount as paper, the proceeds of which have been or are to be used for commercial or industrial purposes. ${ }^{16}$

Collateral notes of Federal Farm Loan Banks, secured by farm loan bonds or the note of a Joint Stock Land Bank, secured by its own bonds, are not eligible for discount. ${ }^{17}$ Federal Farm Loan Bank bonds are not eligible for discount, and are not, accordingly, eligible as collateral for member banks. ${ }^{18}$ A note, secured by paper eligible for discount, is not itself eligible for discount unless its proceeds have been used, or are to be used, for industrial, agricultural or commercial purposes. ${ }^{19}$ Under the present definitions of a trade acceptance, it seems that a draft drawn for an insurance premium would not be eligible for discount. ${ }^{20}$ The note of a farmer given for a tractor to be used on his farm may be discounted as agricultural paper. ${ }^{21}$ A note given by a farmer for the purchase price of a commodity can be classed as agricultural paper eligible for rediscount when having a maturity in excess of ninety days, if the maker is to use the commodity for agricultural purposes, regardless of whether the note is discounted by the maker or the endorser; but if not intended for such use, then the paper is eligible for discount as commercial paper, if having a maturity not in excess of ninety days. ${ }^{22}$
16 Ibid., 6: 699.
${ }^{19}$ Ibid., 4: 108.
${ }^{17}$ Ibid., 6: 609.
${ }^{20}$ Ibid., 4: 309.
18 Ibid., 4: 33.
${ }^{21}$ Ibid., 4: 309. 
A member bank having acquired eligible paper in due course from a non-member bank may discount such paper with a Federal Reserve Bank.23 A note, the proceeds of which is used for tilling or draining farms, may be classed as agricultural paper and is eligible for discount. ${ }^{24}$ A note of a nonmember bank, secured by notes of the government of the United States, and given for the purpose of carrying or trading in such notes of the United States, is eligible for discount when presented by a member bank. ${ }^{25} \mathrm{~A}$ member bank may obtain the discount of its paper secured by government bonds for a period as long as ninety days, by acting through another member bank, although a member bank, acting alone, may not tender its collateral note to the Federal Reserve Bank for a longer period than fifteen days. ${ }^{26}$ Silos are permanent improvements, and notes given for their purchase are not eligible for discount. ${ }^{27}$ Where a railroad company purchases supplies and accepts the draft of the seller and the seller discounts the draft with a member bank, such draft is eligible for discount. ${ }^{28}$ The six months' maturity privilege as applied to agricultural paper does not apply to the sales a manufacturer of implements makes to a dealer for re-sale to a farmer. ${ }^{29}$ The actual sale of goods, and not what is generally termed a conditional sale, must be the basis of a trade acceptance. ${ }^{30}$

A draft drawn to cover the purchase price of goods sold, plus the cost of installing those goods, is eligible for discount. ${ }^{31}$ A note is not eligible for discount as commercial paper unless made and endorsed by a party to the

$\begin{array}{ll}{ }^{23} \text { Ibid., 4: 520. } & { }^{27} \text { Ibid., 4:971. } \\ { }^{24} \text { Ibid., 4:743. } & 28 \text { Ibid., 4: 974. } \\ { }^{25} \text { Ibid., 4:743. } & { }^{29} \text { Ibid., 4: 1118. } \\ { }_{26}^{26} \text { Ibid., 4:863. } & { }^{30} \text { Ibid., 5: } 964 .\end{array}$

${ }^{31}$ Ibid., 4: 310. commercial transaction, out of which it arises. ${ }^{32}$ This is but another way of saying that the proceeds must be used in the first instance for a commercial purpose by the borrower. It is merely emphasizing the thought that paper to be eligible, must be issued or drawn under such circumstances that, in the normal course of business, there will automatically come into existence a fund available to liquidate each piece of paper, that fund being the final proceeds of the transaction out of which the paper arose.

A note of a grain dealer or other purchaser of grain, given to a grower for grain purchased for re-sale, is commercial paper and is to be discounted as such, even though the grower subsequently discounts the note and uses the proceeds for an agricultural purpose. The same principle applies to a draft drawn by the grower, and accepted by the purchaser, in whole or in part payment for grain purchased for re-sale. ${ }^{33}$ Here is brought into play the rule that the transaction out of which an instrument arises in the first instance determines its classification, irrespective of any transaction in which the instrument may be subsequently negotiated.

A note given for the purchase of a motor truck by a farmer is clearly held to be eligible for discount, as agricultural paper, but notes or trade acceptances given in the purchase of motor trucks of a corporation engaged in the business of furnishing motor transportation are not eligible for discount, as such trucks represent in a large extent the corporation's capital investment..$^{34}$

Paper, the proceeds of which are to be used to make loans to third parties, is finance paper rather than commercial or agricultural paper and is not eligible

$$
{ }^{32} \text { Ibid., 7: 1079. } \quad{ }^{33} \text { Ibid., 7: } 1199 .
$$

${ }^{34}$ Ibid., $7: 191$. 
for discount. ${ }^{35}$ Where a cold storage company uses the proceeds of its notes to make advances to customers who have placed their goods in the company's warehouse to be sold by the company for the account of the customers, and the customers give the storage company their notes for the amount of these advances, and as security for such notes, pledge the warehouse receipts, and the storage company pledges the customers' notes and the warehouse receipts as collateral for their own notes, such notes are not eligible for discount. ${ }^{36}$ Growers' drafts accepted by coöperative marketing associations are eligible for discount with Federal Reserve Banks, as agricultural paper, and may have a maturity not in excess of six months. ${ }^{37}$ The note of an irrigation company cannot be classed as agricultural paper, but a farmer's note, given to an irrigation company in payment for a supply of water, may be regarded as agricultural paper. ${ }^{38}$

Notes of corporations or associations engaged in packing and marketing fruits should not be classed as agricultural paper, but as commercial paper, and such notes are eligible when their maturities do not exceed ninety days. The business of such corporations or associations in the marketing of fruits is a commercial business rather than an agricultural business. ${ }^{39}$

\section{The Function of Bankers' ACCEPTANCES}

As already noted, Federal Reserve Banks may discount, for their member banks, bankers' acceptances. A bankers' acceptance is defined by the regulations of the Federal Reserve Board as "a draft or bill of exchange, whether payable in the United States or abroad, and whether payable in dollars or some

\footnotetext{
${ }^{35}$ Federal Reserve Bulletin, 6: 1176.

${ }^{36}$ Ibid., 7: $308 . \quad$ is Ibid., 7: 964 .

${ }^{37}$ Ibid., 7: $1199 . \quad{ }^{39}$ Ibid., 7:1312.
}

other money, of which the acceptor is a bank or trust company, or a firm, person, company or corporation engaged generally in the business of granting bankers' acceptance credits."

The practice of banks to make acceptances is practically as old as the business of banking, but the practice never came into modern use in the United States until after the enactment of the Federal Reserve Act. Prior to that Act the average American bank merely collected the idle funds of the community and loaned them and its own funds to its customers. The bank loaned capital and not credit. On the other hand, the chief merit and the distinguishing feature of European banking systems, especially in England, France and Germany, was found in the bank acceptances by which those banks loaned their credit. They standardized bills of exchange and added new power to them, so that by virtue of their credit quality these bills became, part of the circulating credit of the country. The European banks found the acceptance to be the cheapest form of credit instrument. It did not deplete cash holdings of the accepting bank and no reserve was needed to safeguard the risk. This acceptance power of European banks enabled them cheaply to finance export and import transactions and, doubtless, to a large extent explains why, prior to the Great War, all such financing was done by European banks to the utter exclusion of the American banks.

This salutary method of financing transactions was grafted on our system by the Federal Reserve Act and following that Act most of the states have conferred the acceptance power upon their state banks by specific provision, so that the granting of acceptances by banks has come to be a part of the general banking business in this country. 


\section{The Discount and Purchase of} Bankers' ACCeptances

The Federal Reserve Act and the regulations of the Federal Reserve Board made pursuant thereto, and the Acts of the various states, have safeguarded the granting of acceptances by member banks. Indeed it may be said in broad general terms that bankers' acceptances, which have had their origin in accordance with the limitations of the Act and regulations, if not of more than three months' maturity, exclusive of days of grace, are eligible for discount by Federal Reserve Banks.

Federal Reserve Banks may discount any bill drawn by a bank or banker in a foreign country or dependencies or insular possessions of the United States for the purpose of furnishing dollar exchange as provided in the Act and regulations of the Board, provided such draft has not more than three months' maturity, exclusive of days of grace.

Bankers' acceptances, to be eligible for discount, may involve: (1) the shipment of goods between the United States and any foreign country, or between the Uilited States and any of its dependencies or insular possessions, or between foreign countries; (2) a shipment of goods within the United States; or (3) the storage of readily marketable staples.

When the acceptance is based on a shipment of goods between the United States and any foreign country, or between the United States and any of its dependencies or insular possessions or between foreign countries, shipping documents covering goods in process of shipment need not be attached to the draft drawn for financing the transaction. Neither is it essential that each draft cover specific goods actually in existence at the time of the acceptance, but, in order that said drafts be eligible for discount, it is necessary either, (1) that shipping documents or documentary export draft be attached at the time the draft is presented for acceptance, or (2) if the goods have not been shipped, that there be in existence a bona fide contract providing for the exportation or importation of such goods and that the customer agree that the accepting bank will be furnished in due course with shipping documents or with exchange arising out of the transaction. A contract between principal and agent will not be considered such bona fide contract.

In the case of shipment of goods within the United States, the regulations provide that shipping documents conveying security title should be attached to the draft at the time of its acceptance.

A bankers' acceptance based upon the storage of readily marketable staples must be secured at the time of acceptance by a warehouse, terminal or other similar receipt, conveying security title to such staples, and the acceptor must remain secured throughout the life of the acceptance.

The discretion of the Board with reference to bankers' acceptances and the investment therein of the Federal Reserve Bank funds is probably broader than its discretion with reference to notes, drafts, trade acceptances, and other bills of exchange. ${ }^{40}$

The rule of the Board with reference to furnishing shipping documents in export or import transactions is not met by the furnishing of freight receipts or non-negotiable copies of bills of lading. ${ }^{41}$

Shipping documents are legally in the possession of an accepting bank when they are held by its correspondent or by some other independent party, as its agent, both in domestic and foreign transactions. ${ }^{42}$ The period

$$
{ }^{40} \text { Ibid., 7: 70. }{ }^{41} \text { Ibid., 7: } 191 .
$$


for which drafts may be accepted in the first instance should be approximately the same as that required to complete the shipment and finance the transaction involved. ${ }^{43} \mathrm{~A}$ draft drawn by an American exporter, covering cotton consigned to his European agent, may be eligible for discount, when shipping documents covering goods actually shipped are attached at the time the draft is presented for acceptance, although the goods covered by the documents have not been sold, but are merely shipped on consignment to the agent abroad. ${ }^{4}$

A Federal Reserve Bank may purchase a bankers' acceptance from the drawer or even from the accepting bank, but there is no obligation upon a Federal Reserve Bank to purchase paper offered it, even though the paper is technically eligible. ${ }^{45}$ Where a farmer draws a draft on his local bank for three or four months, secured by bills of lading covering the shipment of cattle to the farmer for feeding, and the local bank accepts the draft and the farmer then discounts it with another bank, such draft is eligible for discount if it has a maturity not in excess of three months. ${ }^{46}$

Bankers' acceptances, growing out of export or import transactions, having a maturity of not more than six months may be purchased in the open market by Federal Reserve Banks.47 The "shipping documents" to be furnished banks accepting drafts growing out of export or import transactions mean an order bill of lading, or a straight bill of lading, whichever is issued by the carrier in the particular case. They do not include freight receipts or mere copies of original bills of lading, but these documents may be held by a correspondent or agent. ${ }^{48} \mathrm{~A}$

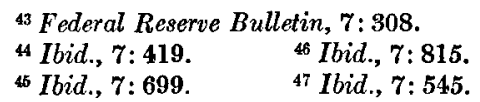

bankers' acceptance drawn by a coöperative marketing association, secured by warehouse receipt covering nonperishable agricultural commodities stored in warehouses independent of the association, is eligible for discount. The acceptance of drafts, secured by bills of lading, for the primary purpose of providing the borrower with working capital during the period required to manufacture and re-sell the goods covered by the bills of lading, is an abuse of a domestic acceptance privilege. ${ }^{49}$ Drafts drawn by the purchaser of goods and secured at the time of acceptance by bills of lading covering the goods bought are not eligible unless the proceeds are to be used to pay for the goods..$^{50}$

A bankers' acceptance secured by a warehouse receipt covering an automobile or automobile tires is not secured by "readily marketable staples" and is not eligible for discount, but an acceptance secured by a bill of lading covering an automobile or automobile tires in the process of shipment, providing the acceptance otherwise complies with the terms of the law or the regulations of the Board, is eligible for discount..$^{51}$ A bankers' acceptance is not eligible for discount if, at the time of its acceptance, the period required for a conclusion of the transaction out of which the original draft was drawn, shall have elapsed. ${ }^{52} \mathrm{~A}$ draft drawn abroad, payable in the United States in dollars, and secured by a warehouse receipt covering readily marketable staples stored in a warehouse in a foreign country, is eligible for acceptance by a member bank and for discount by a Federal Reserve Bank, if of appropriate maturity. ${ }^{53}$

The Federal Reserve Board has defined a "readily marketable staple" as

\footnotetext{
${ }^{49}$ Ibid., 6: 1301. $\quad{ }^{51}$ Ibid., 6: 65.

Bo Ibid., 3: 380; 6: 66 . 52 Ibid., 5: 858.
} 
an article of commerce, agriculture or industry, of such uses as to make it the subject of constant dealings in ready markets, with such frequent quotations of prices as to make the price easily and definitely ascertainable, and the staple itself easy to realize upon by sale at any time. ${ }^{54}$

Under the terms of Section 13 of the Act, any draft or bill of exchange, which a member bank has the power to accept under the provisions of that section, is technically eligible for rediscount by a Federal Reserve Bank. ${ }^{55}$

An accepting bank, secured in a domestic transaction by shipping documents or warehouse receipts, at the time of acceptance may release the shipping documents or warehouse receipts prior to payment, providing the draft or drafts accepted for one person do not exceed 10 per cent of the capital and surplus of the accepting bank. ${ }^{56} \mathrm{Mem}$ ber banks may legally accept drafts drawn against them, secured by sugar placed in bond under transit entry and warehouse receipt issued by the collector in negotiable form. ${ }^{57}$ National banks may not accept a draft which is secured by a chattel mortgage on cattle. ${ }^{58}$ Where a dealer is engaged in purchasing the same character of goods for export and domestic use, a member. bank accepting his draft drawn to' finance an export transaction should require proper assurance that the proceeds of such draft will be used for the purchase of goods for export and that the acceptance will be paid out of the proceeds of sales of goods exported.$^{59}$

A trust receipt in the hands of an accepting bank which permits the purchaser of the goods to procure control of the goods is not actual security, within the meaning of the Act. ${ }^{60}$ One in the possession of a bill of lading cov-
64 Ibid., 5: 652.
55 Ibid., 5: 255.
${ }^{66}$ Ibid., 4: 634 .
57 Ibid., 4: 520 .
68 Ibid., 4 ; 437.
${ }^{69}$ Ibid., $4: 314$.

ering a domestic shipment of goods may not procure an acceptance thereon by a member bank without regard to the use to which the proceeds of the draft are to be put. There must be more than a casual connection between the drawing of the draft and the transaction involved.61 $\mathrm{A}$ warehouse receipt, to be appropriate security for an acceptance, should be issued by a warehouse which is independent of the borrower. ${ }^{62}$ Gold bars may be properly considered as "goods" and, accordingly, sixty day bills, when accepted by banks against such a shipment, would be eligible for discount. Exchange drawn to finance a shipment of gold coin from the Uuited States to Europe or Canada, is eligible for purchase when otherwise in conformity with the Act and regulations. ${ }^{63}$

A bankers' acceptance secured by a bill of sale of stock on hand is not eligible for discount. ${ }^{64} \mathrm{~A}$ bankers' acceptance secured by chattel mortgage on cattle is eligible for discount ${ }^{65}$ but the Board has ruled that a national bank may not accept a draft so secured.66

\section{Paper Must Be Kept Liquid}

The conservation of the strength of the Federal Reserve System is dependent upon the strict adherence of the Federal Reserve Banks to the rules governing the eligibility of paper for discount. If those rules are adhered to, the portfolios of the Reserve Banks will be filled with liquid securities maturing from day to day, thus bringing into the banks a continuous flow of money to meet the demands of commerce and trade. On the other hand, if those rules are departed from, the portfolios of the banks will become clogged with "frozen credits," and the purpose for which the Reserve Banks were organized will be defeated.
61 Ibid., 3: 380.
62 Ibid., 3: 30.
63 Ibid., 3: 29.
64 Ibid., 2: 684.
65 Ibid., 2: 65.
${ }^{66}$ Ibid., 4: 309. 